\title{
Antibacterial and antifungal activities of crude plant extracts from Colombian biodiversity
}

Jaime Niño ${ }^{1}$, Oscar M. Mosquera ${ }^{1} \&$ Yaned M. Correa ${ }^{2}$

1. Grupo de Biotecnología-Productos Naturales, Escuela de Tecnología Química, Universidad Tecnológica de Pereira, A.A.97, Pereira, Colombia; janino@utp.edu.co,omosquer@utp.edu.co

2. Grupo de Biotecnología-Productos Naturales, Departamento de Química, Universidad de Caldas, A.A. 275, Manizales, Colombia; yaned.correa@ucaldas.edu.co

Received 21-X-2011. Corrected 25-V-2012. Accepted 26-IV-2012.

\begin{abstract}
On a global scale, people have used plants to treat diseases and infections, and this has raised interest on the plant biodiversity potencial in the search of antimicrobial principles. In this work, 75 crude $n$-hexanes, dichloromethane and methanol extracts from the aerial parts of 25 plants belonging to four botanical families (Asteraceae, Euphorbiaceae, Rubiaceae and Solanaceae), collected at the Natural Regional Park Ucumari (Risaralda, Colombia), were evaluated for their antibacterial and antifungal activities by the agar well diffusion method. The antibacterial activities were assayed against two Gram-positive bacteria Staphylococcus aureus and Bacillus subtilis, and three Gram-negative ones named, Klebsiella pneumoniae, Escherichia coli and Pseudomonas aeruginosa. In addition, the same plant extracts were tested against the yeast Candida albicans and the fungi Aspergillus fumigatus and Fusarium solani. Overall, the plant extracts examined displayed better bactericide rather than fungicide activities. In general, the best antibacterial activity was showed by the plant extracts from the Rubiaceae family, followed in order by the extracts from the Euphorbiaceae and Solanaceae ones. It is important to emphasize the great activity displayed by the methanol extract of Alchornea coelophylla (Euphorbiaceae) that inhibited four out of five bacteria tested (B. Subtilis, P. aeruginosa, S. aureus and E. coli). Furthermore, the best Minimal Inhibitory Concentration for the extracts with antifungal activities were displayed by the dichloromethane extracts from Acalypha diversifolia and Euphorbia sp (Euphorbiaceae). The most susceptible fungus evaluated was F. Solani since $60 \%$ and $20 \%$ of the dichloromethane and methanol extracts evaluated inhibited the growth of this phytopathogenic fungus. The antimicrobial activity of the different plant extracts examined in this work could be related to the secondary metabolites contents and their interaction and susceptibility of pathogenic microorganism evaluated. Rev. Biol. Trop. 60 (4): 1535-1542. Epub 2012 December 01.
\end{abstract}

Key words: antimicrobial activity, bactericide, bioprospection, fungicide, MIC, well diffusion assay.

Crude plant extracts have been used in folk medicine for treatment of abscesses, insect bites, mycosis, inflammations, intestinal helminths, diarrhoea among others ills (Holetz et al. 2002). This medicinal potential has led the pharmaceutical industry to search for more effective agents, with the aim to discover potentially useful active constituents that can serve as new medicinal molecules or templates for the synthesis of new drug entities (Pretorius et al. 2003; Newman \& Cragg 2007).
In an effort to discover new lead compounds many research groups have screened plant extracts to detect secondary metabolites with relevant biological activities (Harish et al. 2007). The search for new antimicrobial compounds is particularly important, since bacteremia remains a significant cause of morbidity and mortality in many nosocomial infections worldwide. The treatment of patients with bacteremia nowadays is becoming more complicated, because the increasing microbial resistance 
against the limited number of available commercial antimicrobial agents (Davies 2007). In addition, pathogenic strains of bacteria and fungi are especially prevalent in immunecompromised patients, causing many deceases annually. Hence, alternative therapies are urgently needed to treat patients affected by pathogenic microorganisms.

Colombia is a biodiverse rich country although, many plant species are at risk of extinction due to factors such as inadaptability problems associated to climate change conditions as well as anthropic actions, among others. The aim of this work was to investigate the bactericide and fungicide activities of 75 plant extracts belonging to 25 species associated to four botanical families, collected at The Natural Regional Park Ucumarí (NRPU), located in the Central Colombian Andean Mountain region (Pereira, Colombia).

\section{MATERIALS AND METHODS}

Plant material: The adult aerial plant samples $(2 \mathrm{~kg}$, leaves and branches) used for this study were collected in May-June 2006 in NRPU with an altitudinal range between 2100-2450m.a.s.1., a temperature average $14^{\circ} \mathrm{C}$ and an rainfall average of $2700 \mathrm{~mm} /$ year. The plants were identified taxonomically by Dr. F.J. Roldán and a voucher specimen for each plant material was deposited at the University of Antioquia Herbarium, Medellín, Colombia (Table 1).

Each plant sample collected was oven dried at $50^{\circ} \mathrm{C}$ with forced air for $72 \mathrm{~h}$. The dry materials were ground to a fine powder and aliquots of $300 \mathrm{~g}$ were extracted by maceration successively with $n$-hexanes, dichloromethane and methanol (thrice with portions of $900 \mathrm{ml}$ for each solvent). In this work the solvents used were analytical grade from Mallickrodt (Phillipsburg, NJ, USA). In all cases, solvents were pulled out and separately concentrated to dryness in a rotary evaporator at $45^{\circ} \mathrm{C}$ under reduced pressure and the extracts were stored at $-10^{\circ} \mathrm{C}$ until further processing (Niño et al. 2006).
Test organisms: The following Grampositive bacteria were assayed Staphylococcus aureus (ATCC 6538) and Bacillus subtilis (ATCC 21556); while, the Gram-negative Klebsiella pneumoniae (ATCC 10031), Escherichia coli (ATCC 9637) and Pseudomonas aeruginosa (ATCC 27853) were used. In addition, for antimycotic screening the yeast Candida albicans (ATCC 18804) and the fungi Aspergillus fumigatus (ATCC 1022) and Fusarium solani (ATCC 11712) were tested. The bacteria were first subcultured in a Müller Hinton nutrient broth (Oxoid, Basingstoke, England) and incubated at $37^{\circ} \mathrm{C}$ for $18 \mathrm{~h}$; while, the fungal strains were subcultured on a Sabouraud dextrose agar (Becton, Dickinson and Co. Sparks, USA) at $25^{\circ} \mathrm{C}$ for $72 \mathrm{~h}$.

The antibacterial activities of crude extracts were evaluated through the agar-well diffusion assay (Ríos et al. 1998). The $n$-hexanes, dichloromethane and methanol extracts were resuspended in ethanol and tested at concentrations of 4.00, 2.00, 1.00, 0.50 and $25 \mathrm{mg} / \mathrm{ml}$; for the different bacteria assayed, cefotaxime at $25 \mathrm{mg} / \mathrm{ml}$ was used as positive control, with the exception of $P$. aeruginosa, for which $0.5 \mathrm{mg} / \mathrm{ml}$ concentration was employed. In all antimicrobial assays ethanol was used as negative control.

The procedures for the antimycotic assays were described by Niño et al. (2003). For these assays, the three different extracts for each plant species were dissolved and tested at the same concentrations employed for the antibacterial tests. Ketokonazole at $0.25 \mathrm{mg} / \mathrm{ml}$ was used as positive control.

Phytochemical screening of plant extracts: Plant extract phytochemical screening was performed by using thin layer chromatography (TLC) on Silica Gel $60 \mathrm{~F}_{254}$ sheets (Merck, Darmstadt, Germany) following the procedure described by Wagner \& Bladt (1996). The systems chloroform-ethyl acetate-methanol $(2: 2: 1)$ was used for methanol extracts elution; while, $n$-hexanes-ethyl acetate $(7: 3)$ was employed for dichloromethane and $n$-hexanes extracts elution, respectively. After development, the phytocompounds were 
TABLE1

Antimicrobial activity and phytochemical screening of plant extracts from Colombian flora

\begin{tabular}{|c|c|c|c|c|c|c|c|c|c|c|c|c|c|c|c|}
\hline \multirow{4}{*}{ Family } & \multirow{4}{*}{$\begin{array}{c}\text { Plant Species } \\
\text { (Voucher number) }\end{array}$} & \multirow{4}{*}{ Extracts $^{1}$} & \multirow{2}{*}{\multicolumn{5}{|c|}{ Antibacterial activity }} & \multirow{2}{*}{\multicolumn{3}{|c|}{$\begin{array}{l}\text { Antimicotic } \\
\text { activity } \\
\text { MIC (mg/ml) }\end{array}$}} & \multirow{2}{*}{\multicolumn{5}{|c|}{ Phytochemical compounds ${ }^{3}$}} \\
\hline & & & & & & & & & & & & & & & \\
\hline & & & \multicolumn{8}{|c|}{ Microorganism² } & \multirow[b]{2}{*}{ I } & \multirow[b]{2}{*}{ II } & \multirow[b]{2}{*}{ III } & \multirow[b]{2}{*}{ IV } & \multirow[b]{2}{*}{ V } \\
\hline & & & 1 & 2 & 3 & 4 & 5 & 6 & 7 & 8 & & & & & \\
\hline \multirow[t]{15}{*}{ Asteraceae } & Mikania leiostachya & $\mathrm{H}$ & - & - & - & - & - & - & - & - & - & - & + & - & + \\
\hline & \multirow{2}{*}{ Benth. (FJR 3924) } & $\mathrm{DC}$ & - & - & - & - & - & - & - & 4.0 & - & - & + & +++ & ++ \\
\hline & & MT & - & - & - & - & - & - & - & - & ++ & + & + & + & - \\
\hline & Calea angosturana & $\mathrm{H}$ & 2.0 & - & 1.0 & - & - & - & - & - & - & - & + & - & - \\
\hline & Hieron. (FJR 3915) & $\mathrm{DC}$ & 4.0 & - & - & - & - & - & - & - & - & + & ++ & + & ++ \\
\hline & & MT & - & - & - & - & - & - & - & 4.0 & ++ & ++ & + & ++ & - \\
\hline & Clibadium funkize & $\mathrm{H}$ & 4.0 & - & - & - & - & - & - & - & - & - & + & + & - \\
\hline & (FJR 3909) & $\mathrm{DC}$ & - & - & - & - & - & - & - & - & + & + & +++ & - & ++ \\
\hline & & MT & - & - & - & - & - & - & - & 4.0 & - & - & ++ & ++ & + \\
\hline & Pentacalia americana & $\mathrm{H}$ & - & - & - & - & - & - & - & - & - & - & - & - & - \\
\hline & (L. f) Cuatrec. (FJR 3916) & DC & - & - & - & - & - & - & - & 4.0 & - & - & ++ & +++ & +++ \\
\hline & & MT & - & - & - & - & - & - & - & - & ++ & +++ & + & - & - \\
\hline & Vernonia canescens & $\mathrm{H}$ & 2.0 & - & 0.25 & - & - & - & - & - & - & - & + & + & + \\
\hline & Kunth (FJR 3908) & DC & 4.0 & - & - & - & - & - & - & - & - & - & +++ & - & +++ \\
\hline & & MT & - & - & - & - & - & - & - & 4.0 & + & + & ++ & ++ & + \\
\hline Euphorbiaceae & Acalypha sp. (FJR 3914) & $\mathrm{H}$ & - & - & - & - & - & - & - & - & - & - & ++ & + & - \\
\hline & & DC & - & - & - & - & - & - & - & 4.0 & + & - & +++ & ++ & ++ \\
\hline & & MT & - & 2.0 & - & - & - & - & - & - & + & - & - & - & + \\
\hline & Tetrorchidium andinum & $\mathrm{H}$ & - & - & - & - & - & - & - & - & - & - & + & + & - \\
\hline & Müll. Arg. (FJR 3927) & DC & - & - & - & - & - & - & - & 4.0 & - & ++ & ++ & +++ & ++ \\
\hline & & MT & - & - & - & - & - & - & - & - & - & + & + & + & + \\
\hline & Acalypha diversifolia & $\mathrm{H}$ & - & - & - & - & - & - & - & - & - & - & ++ & ++ & - \\
\hline & Jacq. (FJR 3917) & DC & - & - & - & - & - & - & - & 1.0 & + & + & ++ & ++ & +++ \\
\hline & & MT & - & - & 4.0 & - & - & - & - & - & + & + & - & - & ++ \\
\hline & Acalypha platyphylla & $\mathrm{H}$ & - & - & - & - & - & - & - & - & - & - & ++ & ++ & - \\
\hline & Müll. Arg. (FJR 3910) & DC & - & - & - & - & - & - & - & - & + & ++ & +++ & + & +++ \\
\hline & & MT & - & 1.0 & 4.0 & 1.0 & - & - & - & - & ++ & + & - & - & + \\
\hline & Alchornea coelophylla & $\mathrm{H}$ & - & - & 4.0 & - & - & - & - & - & - & - & ++ & ++ & - \\
\hline & Pax \& K.Hoffm. (FJR 3906) & DC & - & - & - & - & - & - & - & - & ++ & - & +++ & +++ & ++ \\
\hline & & MT & 4.0 & 1.0 & 1.0 & 1.0 & - & - & - & - & +++ & + & ++ & ++ & + \\
\hline & Euphorbia sp (FJR 3918) & $\mathrm{H}$ & - & - & - & - & - & - & - & - & - & - & - & + & - \\
\hline & & DC & - & - & - & - & - & - & - & 1.0 & - & - & + & + & ++ \\
\hline & & MT & - & - & - & - & - & - & - & - & - & + & - & - & + \\
\hline & Hyeronima macrocarpa & $\mathrm{H}$ & - & - & - & - & - & - & - & - & - & - & + & + & - \\
\hline & Müll. Arg. (FJR 3925) & DC & - & - & - & - & - & - & - & - & + & + & + & +++ & +++ \\
\hline & & MT & 4.0 & 2.0 & - & 4.0 & - & - & - & - & ++ & ++ & +++ & +++ & ++ \\
\hline & Hyeronima antioquiensis & $\mathrm{H}$ & - & - & - & - & - & - & - & - & - & - & ++ & ++ & + \\
\hline & H. Karst. (FJR 3905) & DC & - & - & - & - & - & - & - & 4.0 & - & - & +++ & ++ & + \\
\hline & & MT & - & - & 4.0 & - & - & - & - & - & + & + & + & ++ & ++ \\
\hline & Mabea montana & $\mathrm{H}$ & - & - & - & - & - & - & - & - & - & - & + & ++ & - \\
\hline & Müll. Arg. (FJR 3912) & DC & - & - & - & - & - & - & - & 4.0 & - & - & ++ & - & ++ \\
\hline & & MT & - & 4.0 & 4.0 & 1.0 & - & - & - & - & ++ & ++ & + & + & + \\
\hline Rubiaceae & Cinchona pubescens & $\mathrm{H}$ & - & - & - & - & - & - & - & - & - & - & + & ++ & - \\
\hline & Vahl. (FJR 3902) & $\mathrm{DC}$ & - & - & - & - & - & - & - & 4.0 & - & - & ++ & +++ & - \\
\hline & & MT & - & - & - & - & - & - & - & - & - & - & - & + & +++ \\
\hline & Ladenbergia macrocarpa & $\mathrm{H}$ & - & - & 4.0 & - & - & - & - & - & - & - & + & ++ & - \\
\hline & (Vahl) Klotzsch (FJR 3903) & DC & - & - & - & - & - & - & - & 4.0 & + & - & +++ & +++ & +++ \\
\hline & & MT & - & 4.0 & - & - & - & - & - & - & + & + & - & + & +++ \\
\hline & Palicourea acetosoides & $\mathrm{H}$ & - & - & 4.0 & - & - & - & - & - & - & - & ++ & ++ & + \\
\hline & Wernham (FJR 3904) & DC & - & - & - & - & - & - & - & - & + & ++ & ++ & - & ++ \\
\hline & & MT & - & - & - & - & - & - & - & 4.0 & - & - & + & ++ & ++ \\
\hline
\end{tabular}


TABLE 1. (Continued) Antimicrobial activity and phytochemical screening of plant extracts from Colombian flora

\begin{tabular}{|c|c|c|c|c|c|c|c|c|c|c|c|c|c|c|c|}
\hline \multirow{4}{*}{ Family } & \multirow{4}{*}{$\begin{array}{c}\text { Plant Species } \\
\text { (Voucher number) }\end{array}$} & \multirow{4}{*}{ Extracts $^{1}$} & \multirow{2}{*}{\multicolumn{5}{|c|}{ Antibacterial activity }} & \multirow{2}{*}{\multicolumn{3}{|c|}{$\begin{array}{l}\text { Antimicotic } \\
\text { activity } \\
\text { MIC }(\mathrm{mg} / \mathrm{ml})\end{array}$}} & \multirow{2}{*}{\multicolumn{5}{|c|}{ Phytochemical compounds ${ }^{3}$}} \\
\hline & & & & & & & & & & & & & & & \\
\hline & & & \multicolumn{8}{|c|}{ Microorganism ${ }^{2}$} & \multirow[b]{2}{*}{ I } & \multirow[b]{2}{*}{ II } & \multirow[b]{2}{*}{ III } & \multirow[b]{2}{*}{ IV } & \multirow[b]{2}{*}{ V } \\
\hline & & & 1 & 2 & 3 & 4 & 5 & 6 & 7 & 8 & & & & & \\
\hline \multirow{28}{*}{ Solanaceae } & Palicourea sp. (FJR 3907) & $\mathrm{H}$ & 2.0 & - & - & - & - & - & - & - & - & - & ++ & ++ & + \\
\hline & & $\mathrm{DC}$ & - & - & - & - & - & - & - & - & - & + & ++ & +++ & ++ \\
\hline & & MT & - & - & - & - & - & - & - & - & - & - & - & + & + \\
\hline & Psychothria sp. (FJR 3911) & $\mathrm{H}$ & 2.0 & - & - & - & - & - & - & - & - & - & + & ++ & - \\
\hline & & $\mathrm{DC}$ & - & - & - & - & - & - & - & - & - & - & ++ & + & + \\
\hline & & MT & - & - & - & - & - & - & - & - & - & - & +++ & +++ & ++ \\
\hline & Rubiaceae sp. (FJR 3913) & $\mathrm{H}$ & 0.25 & - & - & - & - & - & - & - & - & - & + & ++ & + \\
\hline & & $\mathrm{DC}$ & 0.25 & - & - & - & - & - & - & - & - & + & ++ & +++ & ++ \\
\hline & & MT & - & 4.0 & 4.0 & 2.0 & - & - & - & - & ++ & + & ++ & +++ & ++ \\
\hline & Solanum brevifolium & $\mathrm{H}$ & - & - & - & - & - & - & - & - & - & - & ++ & ++ & - \\
\hline & Dunal (FJR 3923) & $\mathrm{DC}$ & - & - & - & - & - & - & - & 4.0 & - & ++ & + & +++ & +++ \\
\hline & & MT & - & - & 4.0 & - & - & - & - & - & - & - & + & + & ++ \\
\hline & Solanum ochranthum & $\mathrm{H}$ & - & - & - & - & - & - & - & - & - & - & + & + & - \\
\hline & Dunal (FJR 3922) & $\mathrm{DC}$ & - & - & - & - & - & - & - & 4.0 & + & ++ & ++ & + & ++ \\
\hline & & MT & - & - & - & - & - & - & - & - & + & + & + & + & +++ \\
\hline & Solanum leucocarpum & $\mathrm{H}$ & 0.5 & - & - & - & - & - & - & - & - & - & ++ & + & - \\
\hline & Dunal (FJR 3926) & DC & 0.25 & 0.25 & - & - & - & - & - & 4.0 & - & - & +++ & + & ++ \\
\hline & & MT & 0.5 & 0.25 & - & - & - & - & - & 4.0 & - & - & - & - & +++ \\
\hline & Solanum ovalifolium & $\mathrm{H}$ & - & - & - & - & 4.0 & - & - & - & - & - & + & + & + \\
\hline & Dunal (FJR 3920) & $\mathrm{DC}$ & - & - & - & - & - & - & - & 4.0 & + & + & + & ++ & +++ \\
\hline & & MT & - & - & - & - & - & - & - & - & ++ & ++ & + & - & + \\
\hline & Solanum deflexiflorum & $\mathrm{H}$ & 1.0 & - & - & - & - & - & - & - & - & - & ++ & + & - \\
\hline & Bitter (FJR 3921) & $\mathrm{DC}$ & - & 1.0 & - & - & - & - & - & 4.0 & - & - & +++ & - & +++ \\
\hline & & MT & 0.5 & 0.25 & - & - & - & - & - & - & - & ++ & + & + & +++ \\
\hline & Positive control & & & & & & & & & & 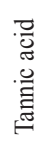 & 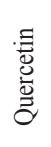 & 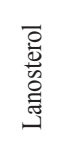 & 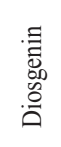 & 芯 \\
\hline & & & & & & & & & & & & & 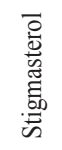 & 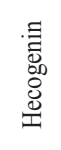 & 咅 \\
\hline & & & & & & & & & & & & & & & $\begin{array}{l}\text { 竞 } \\
\frac{0}{2}\end{array}$ \\
\hline & & & & & & & & & & & & & & & 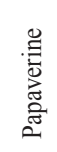 \\
\hline
\end{tabular}

1. Extracts: $\mathrm{H}=n$-hexanes; $\mathrm{DC}=$ Dichloromethane; $\mathrm{MT}=$ Methanol.

2. Microorganism: 1=Bacillus subtilis; 2=Staphylococcus aureus; 3=Pseudomonas aeruginosa; 4=Escherichia coli; 5=Klebsiella pneumoniae; 6=Candida albicans; 7=Aspergillus fumigatus; 8=Fusarium solani .

3. Phytochemical compound: I=Tannins; II=Flavonoids; III=Sterols; IV=Saponins; V=Alkaloids.

$(-)=$ Absent; $(+)=$ Weak content; $(++)=$ Moderate content; $(+++)=$ Strong content . 
visualized through the use of the following chromogenic agents: Dragendorff, anisaldehyde-sulfuric acid, vainillin (1\%) in sulfuric acid-ethanol, ferric chloride (1\%) and aluminum trichloride $(2 \%)$ in ethanol, in order to search for: alkaloids, sterols, terpenes, saponins, phenols, tannins and flavonoids, respectively. All determinations were done in triplicate and standards for the respective natural product assayed were used.

The results for both the antibacterial and antimycotic assays were recorded for each plant extract by determining the concentration in which the inhibition zones near each well were visualized. All tests were carried out in triplicate and repeated twice. Then, the minimum inhibitory concentration (MIC) was obtained.

\section{RESULTS}

Antimicrobial activities: The results from the antibacterial and antifungal activities investigated from the collected plant extracts are reported in table 1.

The results from the antibacterial activities investigated were displayed mainly by Grampositive bacteria, where $36 \%$ of the methanol extracts showed antibacterial activity against $S$. aureus; while, $32 \%$ of the $n$-hexanes extracts displayed antibacterial activity against $B$. subtilis. In addition, $28 \%$ of the methanol and $20 \%$ of the $n$-hexanes plant extracts displayed activity against the Gram-negative bacteria, P. aeruginosa.

The $83 \%$ of the $n$-hexanes extracts of species belonging to the Rubiaceae family examined in this work displayed great bactericidal activity. The antibacterial activity of the previous family was followed by the $78 \%$ of the methanol extracts of species related to the Euphorbiaceae family where the extracts from Acalypha platyphylla Müll. Arg., Alchornea coelophylla Pax \& K. Hoffm., Hyeronima macrocarpa Müll. Arg. and Mabea montana Müll. Arg., displayed MIC values ranging from 1.0 to $4.0 \mathrm{mg} / \mathrm{ml}$ against B. subtilis, $S$. aureus, E. Coli and P. Aeruginosa. In addition, the $60 \%$ of the methanol extracts from members of the Solanaceae family showed activities against the bacteria tested. Solanum leucocarpum Dunal and Solanum deflexiflorum Bitter resulted two of the most active species in this work.

The least active plant extracts in this work was associated to members of the Asteraceae family; however, the dichloromethane and $n$-hexanes extracts from Calea angosturana Hieron. and Vernonia canescens Kunth, displayed good activity against Gram-positive bacteria.

With regards to the antifungal assays, the most susceptible one was $F$. solani, where 15 $(60 \%)$ out of 25 dichloromethane and $5(20 \%)$ out of 25 of the methanol extracts assayed showed activities against this phytopathogenic fungus. The most active dichloromethane plant extracts against $F$. solani were those from the Euphorbiaceae and Solanaceae families with 6 and 5 active extracts, respectively. Acalypha diversifolia Jacq. and Euphorbia sp., displayed the lowest MIC values against this fungus.

Phytochemical screening: The results from the phytochemical screening for the 75 plant extracts examined are listed on table 1, and they showed the presence of sterols, saponins, alkaloids, tannins and flavonoids.

\section{DISCUSSION}

Antibacterial activities: The results reached in this work are related to those obtained for S. aureus (68\%) and B. subtilis (36\%) in a screening performed on some Indian methanol plant extracts (Mahida \& Mohan 2006). In addition, these results are related to the outstanding activity displayed by the crude extracts of some Indian Euphorbiaceae weeds against $P$. aeruginosa (Parmesha et al. 2008).

Results displayed by the Solanaceae family correlate very well with those obtained in the antibacterial assay performed with the alkaloids dimissidine, dihydrosolacongestidine and solasodine isolated from Solanum leucocarpum that displayed MIC values of 250, 125 and $62.5 \mu \mathrm{g} / \mathrm{ml}$, respectively against $S$. aureus; 
the same isolated alkaloids also showed MIC values higher to $1000 \mu \mathrm{g} / \mathrm{ml}$ against $B$. subtilis, P. Aeruginosa, E. coli and K. pneumoniae (Niño et al. 2009).

At the same time, the results showed by the Euphorbiaceae family correlate very well with those reported for Alchornea cordifolia (Euphorbiaceae), which methanol and ethanol extracts displayed MIC values of 1.5 and $2.6 \mathrm{mg} / \mathrm{ml}$, respectively against $S$. aureus (Ajali 2000). Also, the results from this research were in concordance with those reported for Putranjiva roxburghii Wall (Euphorbiaceae) that displayed MIC values ranging from $0.5-4.0 \mathrm{mg} / \mathrm{ml}$, against most of the organisms evaluated (Mahida \& Mohan 2006). Additionally, other extracts, such as the aqueous extract from Euphorbia tirucalli L., at $10 \mathrm{mg} / \mathrm{ml}$ showed antibacterial activity against 11 human pathogenic bacteria (Mohana et al. 2008); furthermore, the ether, hexane and chloroform extracts from Acalypha indica Linn displayed antibacterial activity against E. coli, Aeromonas hydrophila and $S$. aereus (Muthuvelan \& Balaji Raja 2008).

Results displayed by the members of the Rubiaceae family studied were opposite to those found for the methanol extract of Borreria hispida (Linn.) K. Schum., (Rubiaceae) that displayed strong antibacterial activity in the range of 0.25 to $50 \mathrm{mg} / \mathrm{ml}$ (Muthu et al. 2010).

Results related to extracts from the Asteraceae family evaluated here were consistent with those from the petroleum ether extract of Evax pygmaea (L.) Brot. (Asteraceae) that was the most active against $S$. aureus; while, the chloroform extract resulted less potent against the Gram-positives S. epidermidis and Micrococcus luteus (Boussaada et al. 2008).

In general, the best antibacterial activity was showed by the methanol extracts of the species evaluated followed by the $n$-hexanes ones. The antimicrobial effect of methanol extracts against the microorganisms tested may be due to the capability of methanol like solvents to extract some of the active secondary constituents from these plants, such as phenols, alkaloids, saponins, which are reported to have antimicrobial properties (Okwu \& Josiah 2006,
Mothana et al. 2010). Although the low polarity of phytocompounds extracted by $n$-hexanes, they also had phytocompounds that interact in some way with the bacteria assayed and displayed the second order of activities showed in this work.

Plant extracts are rich in many phytocompounds which are the cause of their bioactivities. The mechanism of action of many antimicrobials is complex and may not be the consequence of their action on a single target. In addition, the phenomenon of membrane bleeding has been observed with several antimicrobial agents (Epand et al. 2008). For example, phenolic compounds make their actions through different mechanism, which includes membrane disruption, proteins binding, inhibition of proteins synthesis, enzymes inhibition, production of cell wall complexes, formation of disulfide bridges and intercalation with cell wall and/or DNA, among others (Bozdogan \& Appelbaum 2004). In the same manner, the antimicrobial action of alkaloids could be throughout intercalation with cell wall and/or DNA constituents; while, terpenoids display their action through membrane disruption mechanisms (Cowan 1999).

Antifungal activities: These results correlate very well with those displayed by the crude extracts of Andrachne cordifolia Muell (Euphorbiaceae) (Ahmad et al. 2007), as well as the root extracts of Acalypha gaumeri Pax $\&$ K. Hoffm. and Croton chichenensis Lundell. which were active against the pathogenic fungi Alternaria tagetica, Colletotrichum gloeosporioides, Fusarium oxysporum and Rhizopus sp. (Gamboa-Angulo et al. 2008).

The antimicrobial activity evaluated in this work could be attributed to the presence of different phytocompounds in variable amounts in plant extracts (Table 1). The assayed antimicrobial activity from the plant species depend on the botanical species, the age, the part of the plant studied as well as the solvent used for the extraction procedures (Mahida \& Mohan 2006). 
The fact that the most active extracts showed in this work were active against Grampositive bacteria, is an important aspect, since many of the multidrug-resistant bacteria belong to this category where new chemotherapeutic agents are urgently needed to treat human diseases or to control foodborne microorganisms that originate food spoilage due to microbial resistance to some antimicrobial agents used nowadays in food preservation. These results also provides valuable information for further isolation and characterization studies of active phytocompounds, necessary for the development of new drugs.

Phytochemical screening: In general, the most active plant extracts from the Euphorbiaceae family displayed the presence of tannins and flavonoids; these facts are in consonance with the polyphenols content of some plants from the Euphorbiaceae family that showed condensate and hydrolysable tannins, flavonoids, among others, responsible for their biological activities (Abdulladzhanova et al. 2003). The same way, the alkaloid isolated from the Solanaceae family may be the responsible for the biological activity displayed for these species in this work (Bruneton 2001, Niño et al. 2009).

\section{ACKNOWLEDGMENTS}

The authors are very grateful to The Universidad Tecnológica de Pereira and COLCIENCIAS for the financial support of this project. In addition, the authors are also in debt with the CARDER corporation for granting permission to plant collection.

\section{RESUMEN}

Alrededor del mundo, la gente ha usado las plantas para tratar enfermedades e infecciones, este potencial ha hecho que se incremente el interés en la biodiversidad vegetal como fuente de principios antimicrobianos. En este trabajo, se evaluaron 75 extractos crudos de $n$-hexano, diclorometano y metanol, obtenidos a partir de la parte aérea de 25 especies de plantas proveniente de cuatro familias botánicas (Asteraceae, Euphorbiaceae, Rubiaceae y Solanaceae), colectadas en el Parque Regional Natural Ucumari (Risaralda, Colombia); los cuales fueron evaluados por sus actividades antibacteriana y antifúngica a través del método de difusión en pozo. La actividad antibacteriana fue ensayada frente a las bacterias Gram-positivas Staphylococcus aureus y Bacillus subtilis, y las Gramnegativas Klebsiella pneumoniae, Escherichia coli y Pseudomonas aeruginosa. Adicionalmente, las mismas plantas fueron evaluadas frente a la levadura Candida albicans y los hongos Aspergillus fumigatus y Fusarium solani. En general, las plantas ensayadas mostraron mejor actividad antibacteriana que antifúngica; donde la familia Rubiaceae fue la que presentó mayor actividad antibacteriana, seguida por las familias Euphorbiaceae y Solanaceae. El extracto metanólico de Alchornea coelophylla (Euphorbiaceae) fue el que presentó mejor actividad antibacteriana al inhibir cuatro de las bacteria ensayadas (B. Subtilis, P. aeruginosa, $S$. aureus y E. coli); y los extractos de diclorometano de Acalypha diversifolia y Euphorbia sp. (Euphorbiaceae) fueron los que tuvieron la menor Concentración Mínima Inhibitoria en la actividad antifúngica. El hongo evaluado más susceptible fue $F$. Solani, el cual fue inhibido por el $60 \%$ y el $20 \%$ de los extractos de diclorometano y metanol, respectivamente. Se considera que la actividad biológica de estos extractos, se relaciona con los metabolitos secundarios que ellos contienen y las diferentes susceptibilidades de los microorganismos patogénicos evaluados.

Palabras clave: actividad antimicrobial, bactericida, bioprospección, ensayo por difusión en pozo, fungicida, MIC.

\section{REFERENCES}

Abdulladzhanova, N.G., S.M. Maviyanov \& D.N. Dalimov. 2003. Polyphenols of certain plants of the Euphorbiaceae family. Chem. Nat. Compd. 39: 399-400.

Ahmad, B., S.M.H. Shah, S. Bashir, M. Nisar \& M.I. Chaudry. 2007. Antibacterial and antifungal activities of Andrachne cordifolia Muell. J. Enzym. Inh. Med. Ch. 22: 726-729.

Ajali, U. 2000. Antibacterial activity of Alchornea cordifolia stem bark. Fitoterapia 71: 436-438.

Boussaada, O., J. Chriaa, R. Nabli, S. Ammar, D. Saidana, M.A. Mahjoub, I. Chraeif \& A.N. Helal. 2008. Antimicrobial and antioxidant activities of methanol extracts of Evax pygmaea (Asteraceae) growing wild in Tunisia. World J. Microbiol. Biotechnol. 24:1289-1296.

Bozdogan, B. \& P.C. Appelbaum. 2004. Oxazolidinones: activity, mode of action, and mechanism of resistance. Int. J. Antimicrob. Ag. 23: 113-119.

Bruneton, J. 2001. Farmacognosia. Fitoquímica. Plantas Medicinales. España.

Cowan, M.M. 1999. Plant products as antimicrobial agents. Clin. Microbiol. Rev. 12: 564-582. 
Davies, J. 2007. Microbes have the last word. EMBO Rep. 8: $616-621$

Epand, R.M., R.F. Epand \& P.B. Savage. 2008. Ceragenins (cationic steroid compounds), a novel class of antimicrobial agents. Drug News Perspect. 21: 307-311.

Gamboa-Angulo, M.M., J. Cristóbal-Alejo, I.L. MedinaBaizabal, F. Chí-Romero, R. Méndez-González, P. Simá-Polanco \& F. May-Pat. 2008. Antifungal properties of selected plants from the Yucatan peninsula, Mexico. World J. Microbiol. Biotechnol. 24: 1955-1959.

Harish, B.G., V. Krishna, R. Sharath, H.M. Kumar Swamy, H. Raja Naik \& K.M. Mahadevan. 2007. Antibacterial activity of Celapanin, a sesquiterpene isolated from the leaves of Celestrus Paniculatus Wild Intl. J. Biomed. Pharma. Sci. 1: 65-68.

Holetz, F.B., G.L. Pessini, N.R. Sanches, D.A.G. Cortez, C.V. Nakamura \& B.P. Dias Filho. 2002. Screening of some plants used in the Brazilian folk medicine for the treatment of infectious diseases. Mem. Inst. Oswaldo Cruz 97: 1027-1031.

Mahida, Y. \& J.S.S. Mohan. 2006. Screening of Indian plant extracts for antibacterial activity. Pharm. Biol. 44: 627-631.

Mohana, D.C., S. Satish \& K.A. Raveesha. 2008. Antibacterial evaluation of some plant extracts against some human pathogenic bacteria. ABR. 3-4: 49-55.

Mothana, R.A.A., S.A.A. Abdo, S. Hasson, F.M.N. Althawab, S.A.Z. Alaghbari \& U. Lindequist. 2010. Antimicrobial, antioxidant and cytotoxic activities and phytochemical screening of some Yemeni medicinal plants. eCAM. 7: 323-330.

Muthu, A.K., P. Sravanthi, D.S. Kumar, A.A. Smith \& R. Manavalan. 2010. Evaluation of antibacterial activity of various extracts of whole plant of Borreria hispida (linn). IJPSR 1: 127-130.
Muthuvelan, B. \& R. Balaji Raja. 2008. Studies on the efficiency of different extraction procedures on the anti microbial activity of selected medicinal plants. World J. Microbiol. Biotechnol. 24: 2837-2842.

Newman, D.J. \& G.M. Cragg. 2007. Natural products as sources of new drugs over the last 25 years. J. Nat. Prod. 70: 461-477.

Niño, J., C.M. Espinal, O.M. Mosquera \& Y.M. Correa. 2003. Antimycotic activity of 20 plants from Colombian flora. Pharm. Biol. 41: 491-496.

Niño, J., Y.M. Correa \& O.M. Mosquera. 2006. Antibacterial, antifungal, and cytotoxic activities of 11 Solanaceae plants from Colombian biodiversity. Pharm. Biol. 44: 14-18.

Niño, J., Y.M. Correa \& O.M. Mosquera. 2009. Biological activities of steroidal alkaloids isolated from Solanum leucocarpum. Pharm. Biol. 47: 255-259.

Okwu, D.E. \& C. Josiah. 2006. Evaluation of the chemical composition of two Nigerian medicinal plants. Afr. J. Biotechnol. 5: 257-361.

Parmesha, M., S. Raghvendra, C.K. Ramesh, K.S. Manjunatha \& G. Prakash. 2008. Antibacterial activity of some Euphorbiaceae weeds against pathogens. The Icfal. J. Life Sci. 2: 36-40.

Pretorius, J.C., S. Magama \& P.C. Zietsman. 2003. Growth inhibition of plant pathogenic bacteria and fungi by extracts from selected South African plants species. S Afr. J. Bot. 20: 188-192.

Ríos, J.L., M.C. Recio \& A. Villar. 1998. Screening methods for natural products with antimicrobial activity: A review of the literature. J. Ethnopharm. 23: $127-149$.

Wagner, H. \& S. Bladt. 1996. Plant Drug Analysis. A thin layer chromatography atlas. Springer-Verlag, Berlin, Germany. 